\title{
EXERGY USE IN THE ITALIAN SOCIETY
}

\author{
GÖRAN WALL \\ University of Karlstad, S-651 88 Karlstad, Sweden \\ ENRICO SCIUBBA and VINCENZO NASO \\ University of Rome, Via Eudossiana 18, 00184 Roma, Italy
}

(Received 4 January 1994)

\begin{abstract}
The exergy concept is reviewed as a tool for resource accounting. Conversions of energy and material resources in Italian society are described in terms of exergy. Necessary concepts and conventions are introduced. Exergy losses in transformations of material resources and in the conversion of various forms of energy are described in some detail.
\end{abstract}

\section{INTRODUCTION}

The use of energy and other resources in the industrialized world has reached its highest level yet. As a result, we experience an increasing shortage of natural resources and, as an undesirable side-effect, increasing destruction and pollution of our natural environment. At the same time, the resource-conversion network is becoming very complicated. Technical improvements are often concentrated on relatively less important resource conversions, which can only marginally improve total resource use. Technical solutions sometimes tend to be more sophisticated rather than more efficient, which is the case when electricity produced in a thermal power plant is used for space heating or air-conditioning. By describing the use of resources in society in terms of exergy, we may gain important knowledge and understanding and may also find areas where major improvements ought to be sought by applying more efficient resource conversion. We may then appreciate how convenient it would be to "shift" the resource base towards renewable resources. Even though the "lumped exergy analysis" method may be regarded as simple and approximate, it is an effective tool in the study and improvement of the use of physical resources in modern society. This study is based on concepts and methods presented in earlier work. ${ }^{1,2}$ Similar studies to improve the use of natural resources by applying the concept of exergy to societal systems have been suggested by Szargut, ${ }^{3}$ Moudjan et al, ${ }^{4}$ and Naso et al. ${ }^{5}$

\section{A CLASSIFICATION OF RESOURCES}

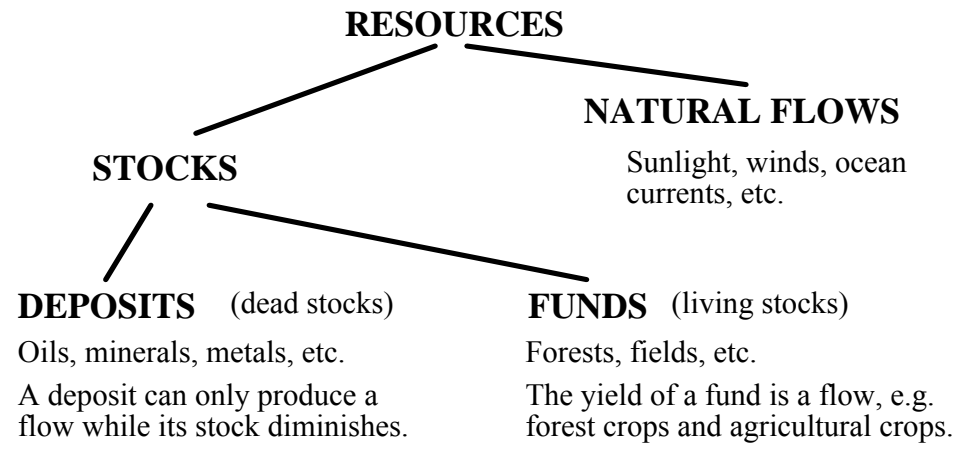

Fig. 1. A classification of resources.

Physical resources, such as energy and material resources, appear partly as flows and partly as stocks (Fig. 1). A natural flow has a limited size or power but usually lasts for a very long time. An ecosystem such as a forest forms a living stock. It is built up of natural flows and gives rise to a flow (yield) that can be taken out of the system without reducing the stock. On the other hand, dead stocks such as oil deposits can only yield a flow if they are gradually 
depleted. Flows from deposits also affect the natural environment through the release of toxic substances.

We therefore differentiate between dead stocks or deposits and living stocks or funds. Deposits and funds are defined with regard to the time of reproduction. Natural flows and flows from funds are often termed renewable flows.

\section{EXERGY AS A GENERAL RESOURCE CONCEPT}

Exergy is the fuel for dissipative systems, i.e. systems that are sustained by converting energy and materials, e.g., a living cell, an organism, an eco-system, the Earth's surface with its material cycles, or a society. The exergy concept could therefore, in this sense, be systematically used to describe such systems.

The concept is mostly used in energy engineering and in cases where one has to deal with energy of varying quality. However, its field of application can be extended to the totality of energy and material conversions in society. This approach yields a uniform description of the use of physical resources and the environmental impact in connection with this use.

Natural resources are traditionally divided into energy resources and other resources. This separation is often only approximate. Oil, for example, is usually looked upon as an energy resource and wood is regarded as a material resource. This distinction is not very meaningful, however, because oil can also be used in the production of useful materials and wood may be used as a fuel. It would be more appropriate to consider these resources together. Exergy is, thus, an adequate resource measure. The exergy content of the energy resources may be given by their energy content multiplied by an exergy factor that applies to the energy form in question (Table 1).

Table 1. The exergy factors of some common energy forms.

\begin{tabular}{|l|c|}
\hline Energy form & Exergy factor \\
Mechanical energy & 1.0 \\
\hline Electrical energy & 1.0 \\
Chemical energy & about $1.0^{\dagger}$ \\
Nuclear energy & 0.95 \\
Sunlight & 0.93 \\
Hot steam $\left(600^{\circ} \mathrm{C}\right)$ & 0.6 \\
District heat $\left(90^{\circ} \mathrm{C}\right)$ & $0.2-0.3^{\dagger}$ \\
Heat at room temperature $\left(20^{\circ} \mathrm{C}\right)$ & $0-0.2^{\dagger}$ \\
Thermal radiation from earth & 0 \\
\hline
\end{tabular}

$\dagger$ May exceed 1, depending on the definition of system boundaries and final states.

\$Depends very much on the outdoor temperature.

In principle, a material can be quantified in exergy units by multiplying its quantity or its mass-flow rate by the appropriate exergy factor for the material. The unit of this factor could then be $\mathrm{J} / \mathrm{m}^{3}, \mathrm{~J} / \mathrm{kg}$ or others. This accounting could be the beginning of an expanded resource budgeting and a first step towards integration with traditional energy budgeting. Thus, exergy per unit quantity is the physical value of a resource as compared to the price, which is the economic value of a resource. Both values are affected by the environment.

Exergy can only denote one extensive physical quality of goods. Exergy does not imply anything about other physical or biological qualities like conductivity, nutritive value, toxicity, etc. However, when a material is used as an exergy converter, the efficiency is related to a quality of interest of the material specific to the particular application. For example a material with poor electric conductivity gives a larger exergy loss than a material with good electric conductivity if both are used as electric conductors.

Energy- and exergy-flow diagrams can be constructed for an entire societal system to track losses and energy degradations which affect the extraction-conversion-utilization system. This 
can be done in general ${ }^{3,6}$ or for a specific society. ${ }^{1,2,7-11}$ In the following sections, an energy/exergy analysis is presented for the Italian society in 1990.

\section{RESOURCE CONVERSIONS IN THE ITALIAN SOCIETY}

The population of Italy has been steadily increasing during this century and was about 57.66 Mpeople in $1990 .{ }^{12}$ The use of natural resources has increased dramatically since the end of the Second World War. Figure 2 shows the use of energy resources from 1963 to $1990 .{ }^{13}$ The population increase during this period was about 7 Mpeople. From this figure, we also see that the total energy use has remained more or less constant since the first dramatic oil-price increase (1973) and that oil and nuclear resources are being replaced by other resources such as natural gas and imported electricity. ${ }^{\dagger}$

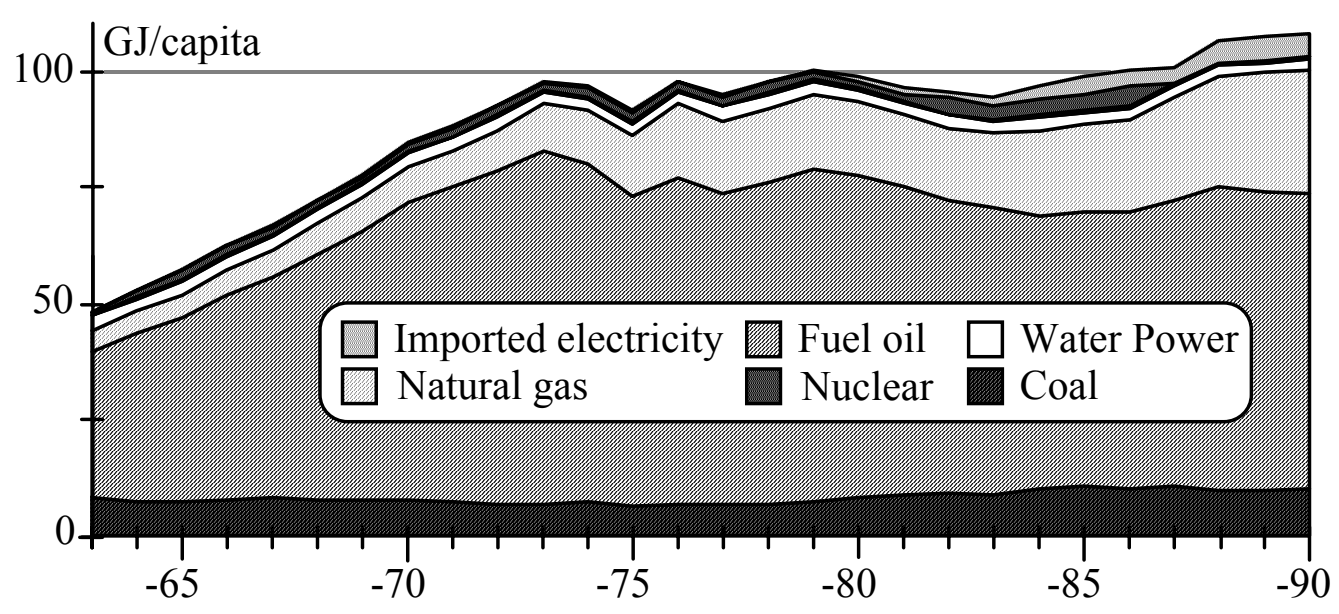

Fig. 2. Energy-resource use in Italy between 1963 and 1990.

The main conversions of energy and materials in the Italian society in 1990 are shown in Fig. 3. Data are based on official statistics. ${ }^{14}$ The values for fossil and renewable resources, as well as those for the purely energy (not material) flows, have been extracted from a very detailed study. ${ }^{5}$ Similar studies have recently been made for Sweden, ${ }^{7}$ Japan, ${ }^{8}$ Finland, ${ }^{9}$ Canada, ${ }^{10}$ and Brazil. ${ }^{11}$ The flows of resources proceed from left to right in the diagram, i.e. from the resource base to the individual. The width of each flow is defined by its exergy content and the unit of the flows is $\mathrm{J} / \mathrm{yr}$. Since the flows vary strongly with time during the year, the unit $\mathrm{J} / \mathrm{yr}$ is preferred to $\mathrm{W}$. The inaccuracies of the flows vary from $5 \%$ for electricity to about $20 \%$ for the heat flows to houses and other premises. In order not to make the diagram too complicated, only major exergy flows are included. The inflows are ordered according to their origins (Fig. 1). Sunlight is thus a natural flow. Harvested forest yields, agricultural yields, and water are flows derived from funds. Geothermal, metals and metal ores, and fossil fuels are flows from deposits. Imported electricity is inserted between funds and deposits since it originates from both. Exergy conversions are represented by the unfilled boxes. The resources actually demanded in society by individuals appear as outflows on the right-hand side of the diagram. The inflow of resources during 1990 totals about $8300 \mathrm{PJ}$ or $140 \mathrm{GJ} / \mathrm{capita}$ and the net output amounts to about $1500 \mathrm{PJ}$ or $25 \mathrm{GJ} / \mathrm{capita}$. The same values for the Swedish

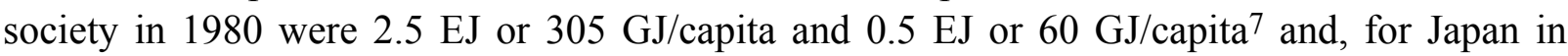
$1985,18 \mathrm{EJ}$ or $150 \mathrm{GJ} /$ capita and $3.8 \mathrm{EJ}$ or $31 \mathrm{GJ} /$ capita. $^{8}$ The large differences are mainly explained by greater uses of wood and paper, about $40 \mathrm{GJ} /$ capita in Sweden compared with about $5 \mathrm{GJ} /$ capita in Japan and $3 \mathrm{GJ} /$ capita in Italy.

\footnotetext{
$\dagger$ Nuclear production of electricity has been halted in Italy since 1987, following a referendum.
} 


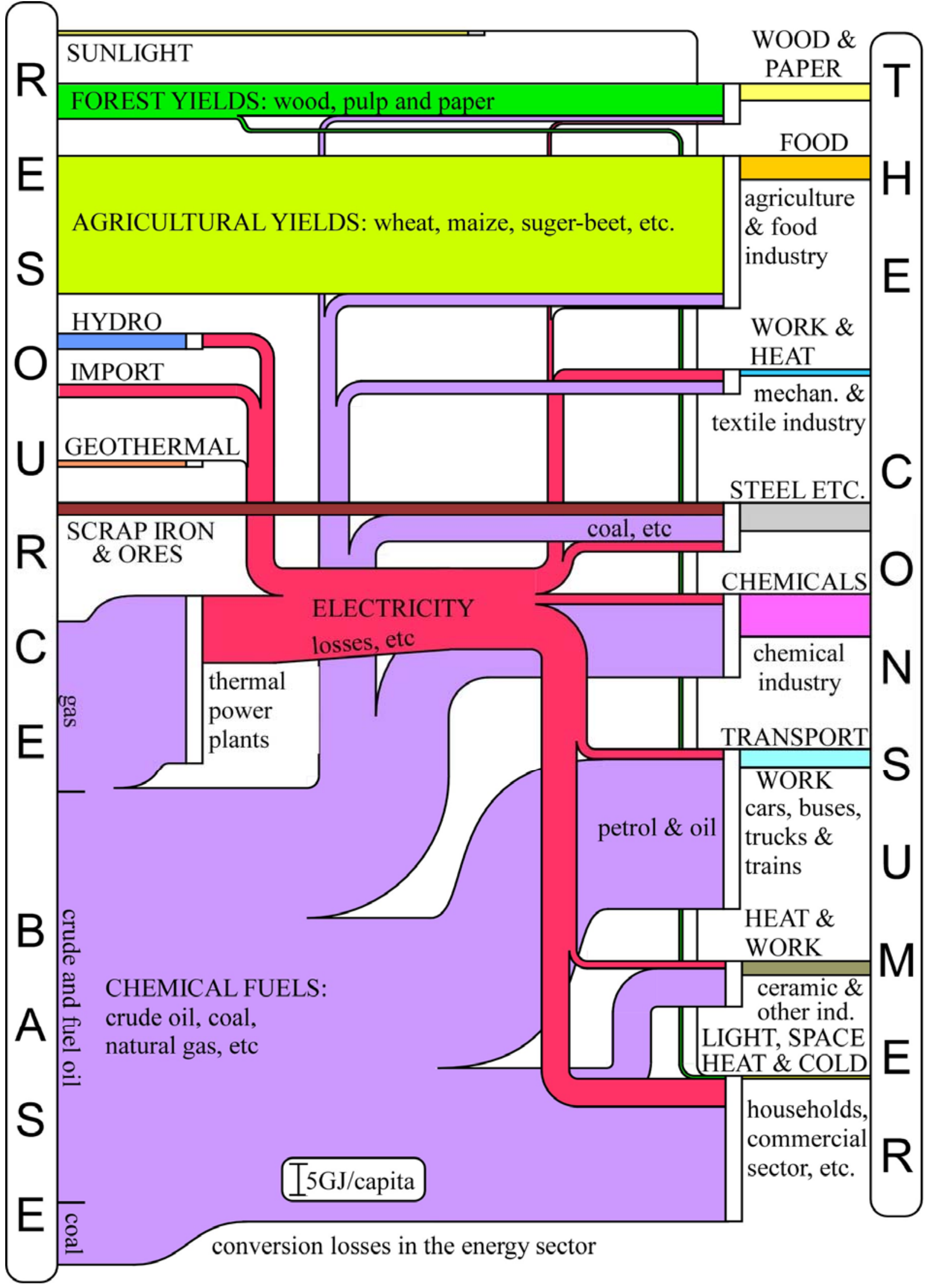

Fig. 3. The exergy-conversion system in the Italian society in 1990. The total input was about $8300 \mathrm{PJ}$ (of which about 6500 are energy related) or $140 \mathrm{GJ} /$ capita and the net output $1500 \mathrm{PJ}$ or $25 \mathrm{GJ} /$ capita

$\left(1 \mathrm{GJ} /\right.$ capita $\left.\approx 57.663 \mathrm{PJ} \approx 16.0175 \mathrm{TWh} \approx 13772.571 \times 10^{9} \mathrm{kcal}\right)$. 


\section{Solar Heating}

The inflow of sunlight, a few PJ, is converted into heat in solar panels. The total inflow of sunlight over the area of Italy is about $1 \mathrm{ZJ} / \mathrm{yr}^{\dagger}$ or $1,000,000 \mathrm{PJ} / \mathrm{yr}$. The converted flow of solar heat supplies the heat for water heating, mainly in households, that can be seen in the bottom right-hand conrner of the diagram. The exergy contents of heat and cold are treated in some detail below. A solar panel could produce about $20 \mathrm{~m}^{3}$ of warm water $\left(40^{\circ} \mathrm{C}\right)$ per year and $\mathrm{m}^{2}$.

\section{Forestry and Industry Based on Forests}

In the Statistical Yearbook of Italy, ${ }^{12}$ the stocks of timber and the raw materials derived from the forests are generally quantified in $\mathrm{m}^{3}$. Wood is used here for many different kinds of wood, e.g., cedar, pine and oak.

The exergy of wood is assumed to be $8 \mathrm{GJ} / \mathrm{m}^{3}$. The exergy content of wood is, in principle, given by the total change of chemical and "structural" exergy. The chemical exergy is the exergy stored in the material as lack of binding exergy between the atoms in a molecule. The structural exergy is the exergy or information stored in the structure of materials. This part is of great value for certain materials such as proteins or cellulose fibers. The structural exergy is well utilized when wood is used as a building material or as a raw material for the production of paper. By burning useful wood, this exergy is utilized very badly. We make better use of the exergy of wood if we only burn structurally useless wood or waste paper. In practice, the structural exergy is often a very small part of the total exergy content of a material but nevertheless very useful.

Forest crops are used for construction and for paper production, as firewood or for charcoal production. The amount of timber cut in Italy was $3.8 \mathrm{Mm}^{3}$ or $31 \mathrm{PJ}(0.53 \mathrm{GJ} /$ capita) for material use and $3.6 \mathrm{Mm}^{3}$ or $29 \mathrm{PJ}(0.50 \mathrm{GJ} /$ capita) for use as firewood. Cutting for char-coal production is negligible or $0.4 \mathrm{PJ}(0.01 \mathrm{GJ} /$ capita $)$. All of this amounts to $1.04 \mathrm{GJ} /$ capita. Imports add $4.79 \mathrm{GJ} /$ capita as wood, timber, pulp, and paper; the total export of mainly paper amounts to $0.46 \mathrm{GJ} /$ capita.

In pulp production, there are heavy losses of exergy due to the conversion of chemical exergy into heat when boiling pulp and manufacturing paper. $5.33 \mathrm{GJ} /$ capita of the forest crops (lignin), together with $0.89 \mathrm{GJ} /$ capita from other fuels and $0.44 \mathrm{GJ} /$ capita of electricity, are transformed to $2.77 \mathrm{GJ} /$ capita of products, heat (from firewood), wood, and paper. Thus, the exergy loss is about $3.89 \mathrm{GJ} /$ capita, which is equivalent to an exergy efficiency of 0.42 .

\section{Agriculture and Food Production}

Harvested crops are converted into food. The inputs in the agriculture and food industries are not only solar radiation but also fertilisers, fuels, and electricity. Food consists partly of vegetable substances such as grains and greens, partly of animal substances such as meat, milk and fish.

The extent of agricultural land in Italy is at present about $121,500 \mathrm{~km}^{2}$ or $41 \%$ of the total land area. The crop yield may vary. The exergy content of the total domestic crops is estimated at about $10 \mathrm{GJ} /$ capita. In addition, there are residues such as straw, harvesting losses and food for animals which, it is estimated, yield about the same exergy. The exergies from fossil fuels (mainly kerosene and fuel oil) and electricity used in agriculture and the food industry were 1.59 and $0.74 \mathrm{GJ} /$ capita, respectively. The import of wheat, other grains and other agricultural products amounted to about $4 \mathrm{GJ} /$ capita (see Table 2). Exports are estimated to be about 1 $\mathrm{GJ} /$ capita. The net import of food then becomes about $3 \mathrm{GJ} / \mathrm{capita}$, which is added to the domestic agricultural yield, i.e. $20 \mathrm{GJ} /$ capita, as input to the food-producing sector.

$\dagger \mathrm{Z}$ (zeta) is the prefix for $10^{21}$. 
Table 2. Agricultural products in Italy in 1990.

\begin{tabular}{|c|c|c|c|c|}
\hline Products & MJ/kilogram & Mton & PJ & GJ/capita \\
\hline $\begin{array}{l}\text { Domestic production } \\
\text { Vegetable products } \\
\text { Wheat } \\
\text { Maize } \\
\text { Other grains } \\
\text { Sugar-beets } \\
\text { Oil-seeds } \\
\text { Olive oil } \\
\text { Other vegetables (estimated) }\end{array}$ & $\begin{array}{c}17.4 \\
16.4 \\
15.2-16.0 \\
4.2 \\
19 \\
19 \\
0.4-24\end{array}$ & $\begin{array}{r}8.05 \\
5.86 \\
3.43 \\
11.92 \\
2.12 \\
0.91 \\
-\end{array}$ & $\begin{array}{r}140 \\
96 \\
54 \\
50 \\
40 \\
17 \\
-\end{array}$ & $\begin{array}{l}2.43 \\
1.67 \\
0.93 \\
0.87 \\
0.70 \\
0.30 \\
3.1\end{array}$ \\
\hline $\begin{array}{l}\text { Total production } \\
\text { Assumed amount of residues } \\
\text { and feedstocks }\end{array}$ & & & & $\begin{array}{l}10 \\
10\end{array}$ \\
\hline Total agricultural yields & & & & 20 \\
\hline $\begin{array}{l}\text { Animal products } \\
\text { Domestic production } \\
\text { Fish } \\
\text { Meat etc. } \\
\text { Milk } \\
\text { Cheese etc. } \\
\text { Other animal prod. (estimated) }\end{array}$ & $\begin{array}{l}2.5-6.5 \\
10 \\
2.7 \\
30\end{array}$ & $\begin{array}{r}0.34 \\
4.13 \\
10.34 \\
0.69\end{array}$ & $\begin{array}{r}2 \\
41 \\
31 \\
21\end{array}$ & $\begin{array}{l}0.03 \\
0.72 \\
0.54 \\
0.36 \\
0.35\end{array}$ \\
\hline Total domestic production & & & & 2 \\
\hline $\begin{array}{l}\text { Imports } \\
\text { Wheat } \\
\text { Maize } \\
\text { Sugar etc. } \\
\text { Meat, etc. } \\
\text { Other prod. (estimated) }\end{array}$ & $\begin{array}{l}17.4 \\
16.4 \\
17 \\
10 \\
-\end{array}$ & $\begin{array}{l}4.67 \\
1.14 \\
0.75 \\
3.28 \\
-\quad\end{array}$ & $\begin{array}{r}81 \\
19 \\
33 \\
-\end{array}$ & $\begin{array}{l}1.41 \\
0.33 \\
0.22 \\
0.57 \\
1.47\end{array}$ \\
\hline Total imports & & & & 4 \\
\hline $\begin{array}{l}\text { Exports } \\
\text { Wheat } \\
\text { Other grains } \\
\text { Other prod. (estimated) }\end{array}$ & $\begin{array}{l}17.4 \\
15.2-16.0 \\
-\end{array}$ & $\begin{array}{l}0.62 \\
1.52 \\
-\end{array}$ & $\begin{array}{r}11 \\
24 \\
-\end{array}$ & $\begin{array}{l}0.19 \\
0.41 \\
0.4\end{array}$ \\
\hline Total exports & & & & 1 \\
\hline
\end{tabular}

Food consumption in Italy is estimated from the daily intake, which is stated to be on average $2600 \mathrm{kcal} /$ day-person or $4 \mathrm{GJ} / \mathrm{capita}$. This value is the outflow from the foodproduction system in Fig. 3. The food-production system in Italy is more efficient than that in Sweden, ${ }^{7}$ probably because of relatively larger intakes of vegetable products and their derivatives (pasta) on the part of Italians.

\section{Electricity from Hydroelectric-power and Thermal Power}

Electricity is used in the forest industry and in food production. Furthermore, electricity is used for lighting, heating, cooling, mechanical drives, electrochemical processes, and other generic uses in households and in the commercial sector. About $1.73 \mathrm{GJ} /$ capita were used in the mechanical and textile industries, $1.6 \mathrm{GJ} /$ capita for metal production (mainly steel), 1.23 $\mathrm{GJ} /$ capita for chemicals, $0.38 \mathrm{GJ} /$ capita in the transportation sector, $0.8 \mathrm{GJ} /$ capita in the ceramic and other industries (e.g., the cement industry), and $5.82 \mathrm{GJ} /$ capita in the household and commercial sectors. In the textile and mechanical industries, most of the electricity was used for driving machines (i.e. mechanical work). In the steel industry, electricity is used for electric furnaces for high-quality products.

In 1990, the production of electricity from hydro-power was $2.19 \mathrm{GJ} /$ capita. If we assume that the conversion losses of potential energy in the dam, transformer losses at the power sta- 
tions and pumping losses in the pumping stations are $15 \%$, then the gross exergy supply is 2.58 $\mathrm{GJ} /$ capita as hydro-power. Geothermal energy $(0.20 \mathrm{GJ} /$ capita $)$ is used in Italy for the production of electricity. With an estimated exergy efficiency of 0.20 , this implies an exergy use of 1 $\mathrm{GJ} /$ capita of geothermal exergy.

Nuclear fuel (U-235) is no longer used in Italy. Only fossil fuels such as natural gas, oil and coal are used to produce electricity. The conversion processes occur in thermal power plants, where $27.74 \mathrm{GJ} /$ capita were used to produce $11.15 \mathrm{GJ} /$ capita of electricity.

The overall domestic production of electricity amounted to $13.55 \mathrm{GJ} /$ capita. Since 2.16 GJ/capita were imported, total electrical use were $15.71 \mathrm{GJ} /$ capita. Of these, $13.39 \mathrm{GJ} /$ capita wer used as specified above. The difference, $2.32 \mathrm{GJ} /$ capita, was lost along the way to consumers due to transport and electrical conversion losses.

\section{Metals}

The Italian metal industry is totally dominated by steel. The use of scrap metal (mainly steel scrap) and ores in 1990 was approximately $3.85 \mathrm{GJ} /$ capita. The production of steel was 25.5 Mton and of cast iron 11.9 Mton, representing $4.47 \mathrm{GJ} /$ capita. $^{2}$ Other metals such as aluminium and zinc add $0.36 \mathrm{GJ} /$ capita, i.e. total metal production used $4.83 \mathrm{GJ} / \mathrm{capita}$. To produce these metals, about $4.43 \mathrm{GJ} /$ capita of coal for coke production and other fuels and 1.67 GJ/capita of electricity were needed.

\section{Chemical Fuels}

By chemical fuels we mean oil and oil products such as kerosene and petrol, coal and coal products such as coke and natural gas. The uses of natural gas, oil, and coal in 1990 amounted to $28.38,68.01$ and $10.22 \mathrm{GJ} /$ capita, respectively.

In the chemical industry, fuels are also used as raw materials. This means that a large fraction of the exergy remains in the products and the relative conversion losses are moderate. $12.11 \mathrm{GJ} /$ capita of chemical fuels were converted into asphalt, grease, lubricants, rubber, plastics, fertilizers, etc. The chemical industry is thus an example of how traditional energy goods such as oil are used as materials. Often, waste materials can then be "recycled" as energy resources. This is also true of many other recyclable materials such as wood and paper.

As we see from the diagram, the transportation system uses $23 \%$ or about $25 \mathrm{GJ} /$ capita of fuel. Petrol and oil are converted into transport work in cars, buses, trucks, etc. Only about 7\% of the exergy of the fuel is used to run a vehicle, of which only a part (persons or goods) constitute useful transport. The average efficiency of the entire transportation system (cars, buses, trucks, rails, ships, and air) was about $10 \%$.

About $7.11 \mathrm{GJ} /$ capita were used by the energy sector for oil refineries and $18.92 \mathrm{GJ} / \mathrm{capita}$ for direct conversion into heat in households, the commercial sector, etc. $27.74 \mathrm{GJ} /$ capita were used for the production of electricity in thermal power plants, $6.33 \mathrm{GJ} /$ capita mainly for heat production in the ceramic industry, and $2.10 \mathrm{GJ} /$ capita were used in the mechanical and textile industries.

\section{Exergy Losses from Conversions into Heat and Cold}

At the bottom of Fig. 3, we show the conversions of fuels, electricity and solar heat mainly into heat at room temperature (space heating) in households. This conversion is shared between apartment houses, family houses, and other premises. As we see, heavy losses appear.

The exergy of heat transfer $Q$ at temperature $T$ is

$$
E=\left|\left(T-T_{0}\right) / T\right| Q
$$


where $T_{0}$ is the reference temperature. The exergy factor $E / Q=\left(T-T_{0}\right) / T$ is the Carnot efficiency.

In space heating, the need of heating is entirely dependent on the ambient temperature. If we consider the indoor temperature, $20^{\circ} \mathrm{C}$ or $293 \mathrm{~K}$, as constant, then the exergy factor of indoor heat varies with the outdoor temperature according to Eq. (1). However, the exergy content will be reduced since, due to poor insulation, the indoor temperature varies with the outdoor temperature. With a temperature difference between indoors and outdoors of $10^{\circ} \mathrm{C}$, the exergy factor of the indoor heat becomes about $0.03 ; 3 \%$ is therefore assumed to be the exergy percentage of the indoor energy during the heating and cooling seasons in Italy. Other losses such as exhaust gases are small in comparison with this loss. Exergy for Italian space heating and air-conditioning is obtained by multiplying the supplied energy by the energy efficiency, which is assumed to be 0.7 with the exergy factor 0.03 , i.e. approx. 0.02 .

\section{CONCLUSIONS}

Of the total inflow of energy and material resources in the Italian society of about $8300 \mathrm{PJ}$ in 1990 , only about $15 \%$ reached its final use. Heavy losses could be considerably reduced by active resource budgeting and economizing at all levels in the society. In particular, building technology needs to be improved. Better insulation would reduce the needs for space heating and air-conditioning. This insulation would also improve indoor comfort.

In the long run, especially from the environmental point of view, the exergy needs of a society must be supplied almost entirely from renewable resources. As we can clearly see from Fig. 3 , this was not the case.

Analyses of exergy use provide knowledge as to how effective and how balanced a society is in the use of natural resources. This type of knowledge can be used to identify areas in which technical and other improvements should be undertaken and also indicates the priorities which should be assigned to conservation measures. Making comparisons of this type between various societies throughout the world and studying the international system should also be of fundamental interest if we are serious in our efforts to work towards a more equitable distribution of resources. However, in order to generalize the use of this technique, statistical data must be improved. Necessary steps should therefore be undertaken by national authorities to establish international agreements to facilitate the gathering and sharing of information.

Acknowledgement-This work was partially supported by ENEL (Italy).

\section{REFERENCES}

1. G. Wall, "Exergy - a Useful Concept within Resource Accounting," Report No. 77-42, Institute of Theoretical Physics, Göteborg, Sweden (1977).

2. G. Wall, "Exergy - a Useful Concept," Thesis, Chalmers University of Technology, S-412 96 Göteborg, Sweden (1986); available on diskette by sending US $\$ 10$ in cash to the author.

3. J. Szargut, Bull. Polish Acad. Sci., Tech. Sci. 34, 475 (1985).

4. G. Mondjan and E. Sciubba, "Energetic and Exergetic Analysis of Various Models of Pre-Industrial, Industrial and Post-Industrial Societies: Limit Trends and Self-Sustainability Issues," in Proc. ENSEC'93, J. Szargut ed., Cracow (1993).

5. V. Naso, E. Sciubba and G. Wall, "Exergetic Analysis of the Energy Flows in the Italian System" (in Italian), Techn Rep. DMA-ENEL-931101, Rome (1993).

6. E. Sciubba, "Modeling the Energetic- and Exergetic Self-Sustainability of Societies with Different Structures," submitted for publication in J. En. Res. Techn. (1993).

7. G. Wall, Resources and Energy 9, 55 (1987).

8. G. Wall, Energy - The International Journal 15, 435 (1990).

9. G. Wall, in P. Malaska and K. Grönfors eds., Publications of the Turku School of Economics and Business Administration, Series C-2:1991, Turku, Finland (1991).

10. M. A. Rosen, Energy - The International Journal 17, 339 (1992).

11. R. Schaeffer and R. M. Wirtshafter, Energy - The International Journal 17, 841 (1992).

12. ISTAT, "Annuario Statistico Italiano," Instituto Nazionale di Statistica, Rome (1991).

13. ENEL, "Produzione e Consumo di Energia Elettrica in Italia," Rome (1991).

14. BEN, "Bilancio Energetico Nazionale," Ministero del'Industria del Commercio e dell'Artigianato, Rome (1990). 